\title{
Characterization and Potential Recovery of Household Solid Waste in the City of Ouagadougou (Burkina Faso)
}

\author{
Kayaba Haro, Issoufou Ouarma, Bernard Nana, Antoine Bere, Jean Koulidiati \\ Laboratoire de Physique et de Chimie de l'Environnement (LPCE), Université Ouaga I Pr Joseph KI-ZERBO, Ouagadougou, \\ Burkina Faso \\ Email: berebiya@yahoo.fr, abere@univ-ouaga.bf
}

How to cite this paper: Haro, K., Ouarma, I., Nana, B., Bere, A. and Koulidiati, J. (2018) Characterization and Potential Recovery of Household Solid Waste in the City of Ouagadougou (Burkina Faso). Journal of Environmental Protection, 9, 309-324.

https://doi.org/10.4236/jep.2018.94021

Received: March 13, 2018

Accepted: April 23, 2018

Published: April 26, 2018

Copyright $\odot 2018$ by authors and Scientific Research Publishing Inc. This work is licensed under the Creative Commons Attribution International License (CC BY 4.0).

http://creativecommons.org/licenses/by/4.0/

(C) (i) Open Access

\begin{abstract}
This study on physical and physicochemical characteristics of household solid waste (HSW) in the city of Ouagadougou by using MODECOM, "Method of Characterization of Household waste" was done fifteen (15) years after the first study. Special attention has been paid to waste sampled and also to estimate energy content, namely the higher heating value (HHV) and the lower heating value (LHV). As a general tendency, the results showed a sensitive evolution in the physical parameters of waste (composition by size and composition by category) and also in the physicochemical parameters (moisture content and energy content). The results of HSW composition study showed that regardless the seasons, fermentable fraction is dominant $39 \%$ in the rainy season and $20 \%$ in the dry season) followed by plastics ( $18 \%$ in the rainy season and $20 \%$ in the dry season). The moisture content is measured to be $56.69 \%$ and $37.69 \%$ respectively in the rainy season and dry season. The results analysis of the potential of recovery showed that the organic recovery is more important (60\% in the rainy season and $55 \%$ in the dry season) than the matter recovery ( $43 \%$ in the rainy season and $46 \%$ in the dry season). These results highlight the need for organic recovery and matter recovery of HSW in the city of Ouagadougou. The results from the analysis of the energy content showed that the HHV is estimated to be $17.94 \mathrm{MJ} / \mathrm{kg}$ in the rainy season and $17.96 \mathrm{MJ} / \mathrm{kg}$ in the dry season. The LHV is calculated to be $6.38 \mathrm{MJ} / \mathrm{kg}$ in the rainy season and $10.27 \mathrm{MJ} / \mathrm{kg}$ in the dry season. These results suggest that incineration as treatment of HSW in the city of Ouagadougou is not economically an appropriate option.
\end{abstract}

\section{Keywords}

Waste Characterization, Waste Recovery, MODECOM, Energy Content, Calorific Value, Ouagadougou 


\section{Introduction}

Solid waste management has become a big concern in many developing countries. The rapid growth of the population, coupled with rapid urbanization and economic growth, and the change in lifestyle and consumption, is accompanied by more and more waste productions. According to Beede and Bloom [1], an increment of $1 \%$ in population growth calls for an increase of $1.04 \%$ in waste production.

In most developing countries, solid waste management remains essentially traditional. Waste is either disposed in uncontrolled and/either controlled landfills or simply burned. This way of managing waste entails enormous risks to the environment and consequently the health of the populations. According to a World Bank [2] report, the use of some technologies of solid waste treatment such as incineration in developing countries failed due to the overestimation of the energy content of waste in these countries, which is rich in organic matter. Then, it is essential to know the physical composition of waste by characterizing it.

Since the year 2000, several studies on the characterization of household solid waste (HSW) in main cities of developing countries especially those of sub-Saharan Africa have been carried out in order to determine their physical, chemical and thermal properties and the conditions under which their management is to be improved [3]-[17]. It is important to know that household solid waste refers to the general waste stream from the municipal collection service.

In 2003, Tezanou et al. [3] reported the first characterization of HSW in the city of Ouagadougou. After more than a decade, the characteristics of these wastes have been evolving with respect the economic and demographic development. It is in this context and also with the objective to update the data on the physical, chemical and thermal characteristics for HSW in the city of Ouagadougou that the present study is done. To conduct our study, the required inputs are HSW at Ouagadougou city, a method for the characterization and laboratory equipment.

As mentioned above, there are many works on the characterization of HSW in main cities of sub-Saharan Africa countries. However, given climate and lifestyles differences in these cities, it appears difficult to predict trends in the presented results. Then, we will discuss the results of the present work with those of the work of Tezanou et al. [3] for year 2003.

\section{Materials and Methods}

\subsection{Materials}

The HSW at Ouagadougou city were used as raw materials. The population of Ouagadougou was estimated to be 2,868,034 habitants in 2017 [18]. With a rate of waste at $0.62 \mathrm{~kg} /$ person/day [8], the generated HSW in the city of Ouagadougou was estimated to be about, 649,480 tons annually in 2017.

xThe equipment and tools used are tarpaulin, three-stage-sorting table, scaled, 
shovels, rakes; brooms, garbage, garbage cars, and protective equipment.

\subsection{Methods}

Two campaigns of characterization were carried out during the year 2017: one in the dry season (February-March) and other in the rainy season (July-August). For each campaign, the MODECOM method [19] was used. This method that was successfully applied in developed countries cannot be fully used in the context of developing countries for the following reasons: 1) collection is irregular and even non-existent in some neighborhoods; 2) city coverage is not total and collected waste cannot be fully representative, even when collection is assured. Given these constraints, this method has been modified [4] [8]. The main modification consists in rather the stratification of study area into homogeneous zones and to the adoption of rigorous protocol to define waste sampled for the sort in composition by size and by category of waste. It should be noted that the quality of the characterization depends on the quality of the waste sampled. Figure 1 presents the organization and the steps applied during the waste composition study.

\subsubsection{Stratification of Study Area}

According to previous works [3] [7] [20], the study area is classified into three zones with respect to the standing of habitats, the state of the road network, the offered social services such as potable water supply, electricity supply and the sanitation infrastructures. These three zones are designated as "high standing", "middle standing" and "low standing". They correspond respectively to "high income class", "middle income class" and "low income class" according to Miezah et al. [7]. The high standing is composed of districts that are very well-off including residential neighborhoods and cities. They exhibit good road network, appreciable social services and modern sanitation infrastructures. The middle standing assembles the well-to-do neighborhoods. They are characterized by a road network including unpaved roads, some level of improved social services and practically non-existent sanitation infrastructures. The low standing is made of peripheral districts, especially non-parceled neighborhoods. The road network, the social services and the sanitation infrastructures are non-existent. The houses are built and installed without any respect for urbanization standards. According to available statistical data [21], the high standing constitutes $11 \%$ of the city occupation, the middle standing $45 \%$ and the low standing $44 \%$. Figure 2 shows the map of the study area and the location of different districts of three zones [20]. In the study area, thirty-five (35) collection centers are counted (Figure 2).

Notice that the step of the stratification of the study area is important to define a representative waste sampled of the city of Ouagadougou.

\subsubsection{Protocol to Define Waste Sample for the Sort by Size}

After stratification, a random draw was conducted to select a collection center 


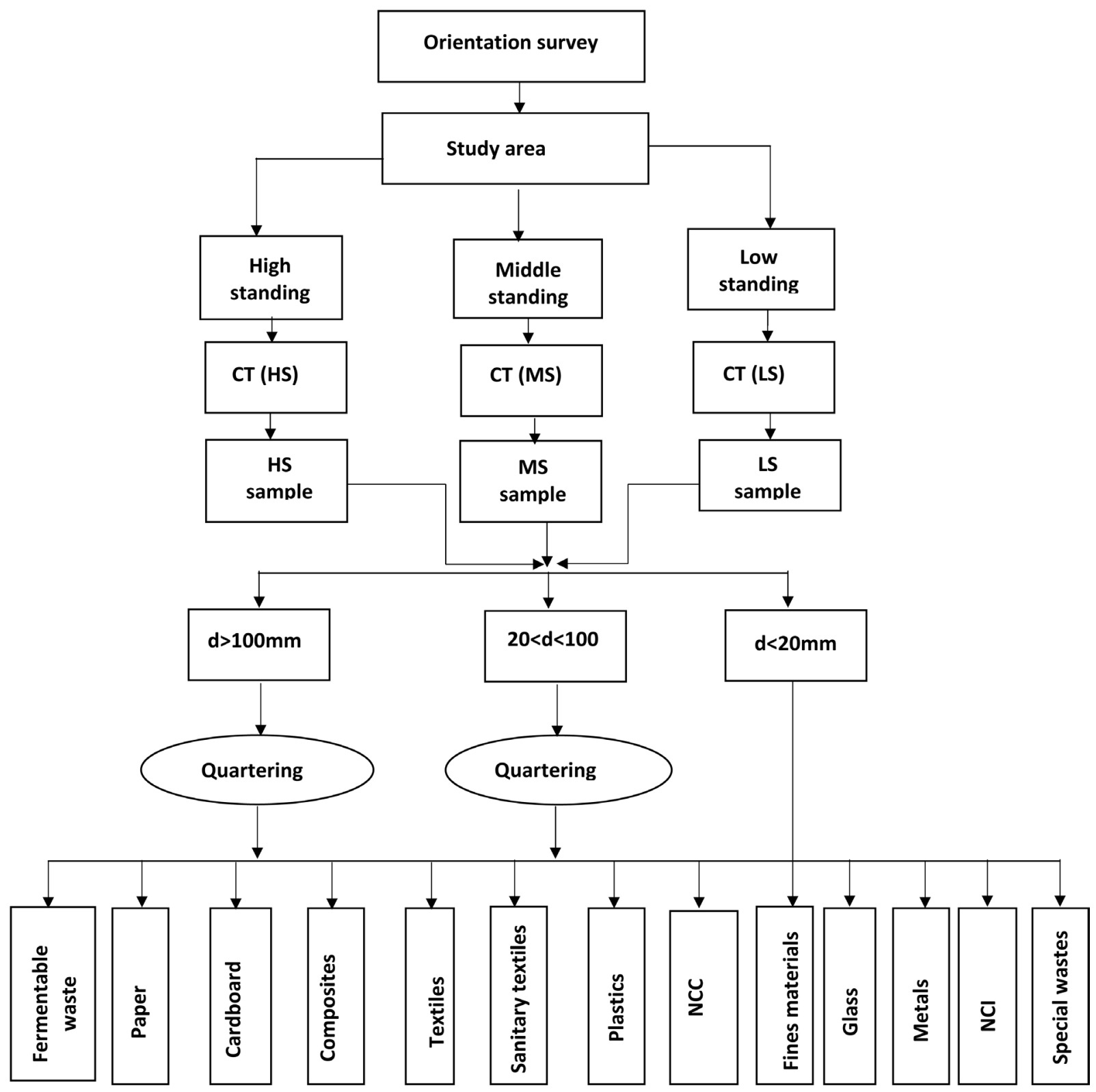

Figure 1. Organization and steps applied during the study of waste composition. CT (collection center); HS (High standing); MS (Middle standing); LS (Low standing); NCC (Non-classified combustibles); NCI (Non-classified incombustibles).

per zone. This center is designated to select collection center. MODECOM method recommends a sample weigh of approximately $500 \mathrm{~kg}$ or higher to submit to the sort by size in order to limit measurement errors. For this propose, for a given zone, wastes of one container of the selected collection center are taken randomly until the recommended weigh of sample is reached. The composition by size will be obtained from the sort of this sample.

\subsubsection{Protocol to Define Waste Sample for the Sort by Category}

After the sort by size, the big and the means fractions will be submitted to quartering operation (Figure 3) if the corresponding fraction mass is higher than 120 $\mathrm{kg}$. Finally, for each fraction, a sample of approximately $120 \mathrm{~kg}$ or lower will be 


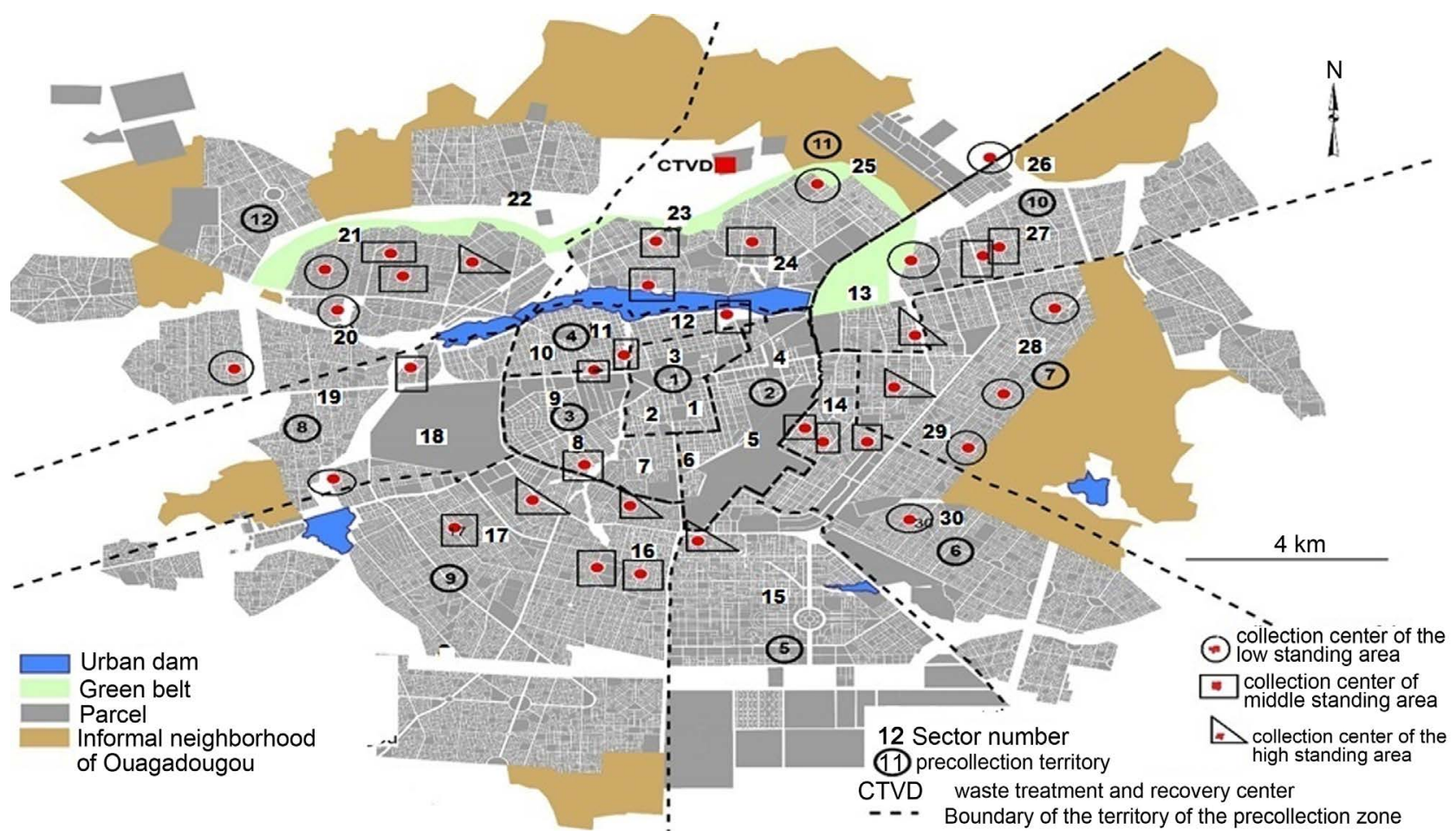

Figure 2. Location of the three major strata and the thirty-five collection centers for characterization of household solid waste in Ouagadougou city [20].

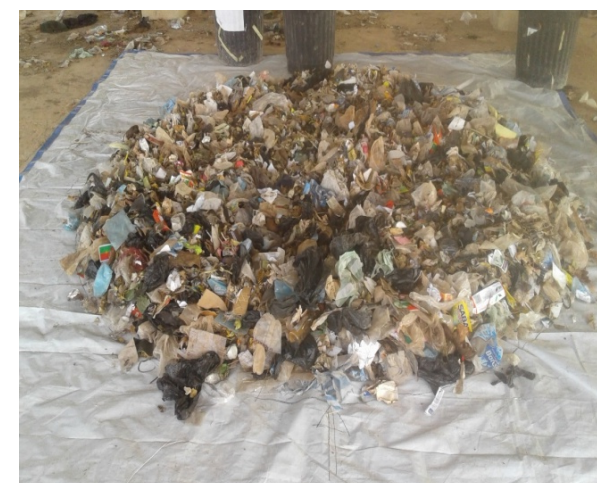

(a)

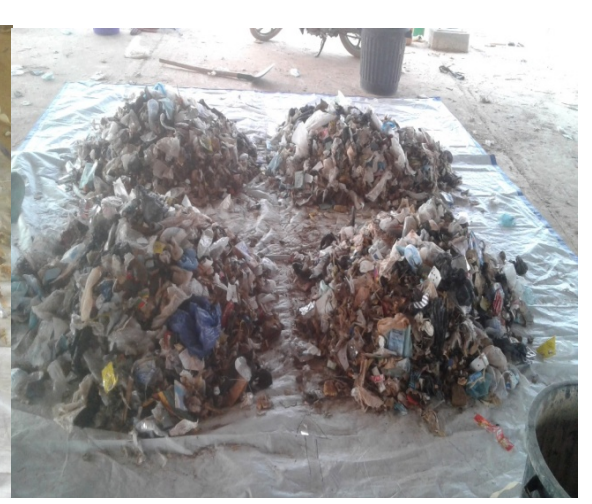

(b)

Figure 3. Quartering operation in order to set the sort sample: (a) homogeneous heap of $3 \mathrm{~m}$ diameter; (b) sample divided into 4 equal parts.

stored from which the composition by category will be calculated.

\subsubsection{Measurement of Waste Parameters}

1) Composition by size

The composition by size is given by sorting out by means of a table of sorting (Figure 4) a separation in three components according to the diameter of particle size $(d)$. They are named: the big $(d>100 \mathrm{~mm})$, the means $(20 \mathrm{~mm}<d<$ $100 \mathrm{~mm})$, the fines $(d<20 \mathrm{~mm})$.

The percentage composition of each of the components of size (percentage composition of size) will be calculated by the formula in Equation (1). 
Percentage composition by seize $=\frac{\text { Weight of separate waste }}{\text { Total of mixed sampled }} \times 100$

2) Composition by category

The big and the means obtained from the size operation are sorted out in twelve (12) categories (Figure 5): fermentable waste, papers, cardboards, composites, textiles, sanitary textiles, plastics, glasses, metals, non-classified combustibles (NCC), non-classified incombustibles (NCI), and special waste [19]. Taking into account the fines elements as a waste category, wastes are sorted into thirteen (13) categories.

The percentage composition of each of the components of waste categories (percentage composition by category) was calculated by the formula in Equation (2).

$$
\text { Percentage composition by category }=\frac{\text { Weight of separate waste }}{\text { Total of mixed sampled }} \times 100
$$

3) Moisture content

Several approaches are used to estimate the moisture content. In the present work, the standard NFM 03-002 recommendation [19] is used and consists for drying $200 \mathrm{~g}$ of a given waste in an oven at $105^{\circ} \mathrm{C}$ for 24 hours until the mass of

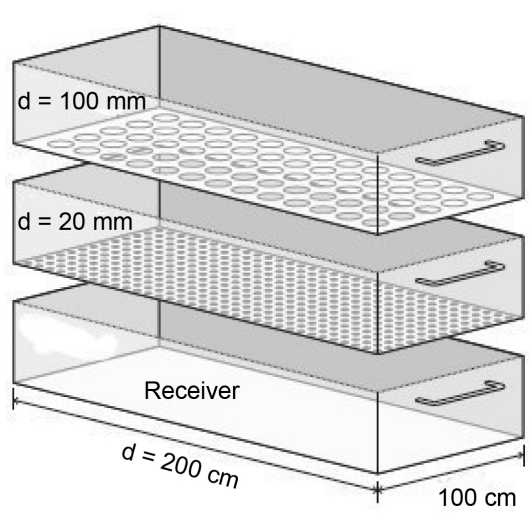

(a)

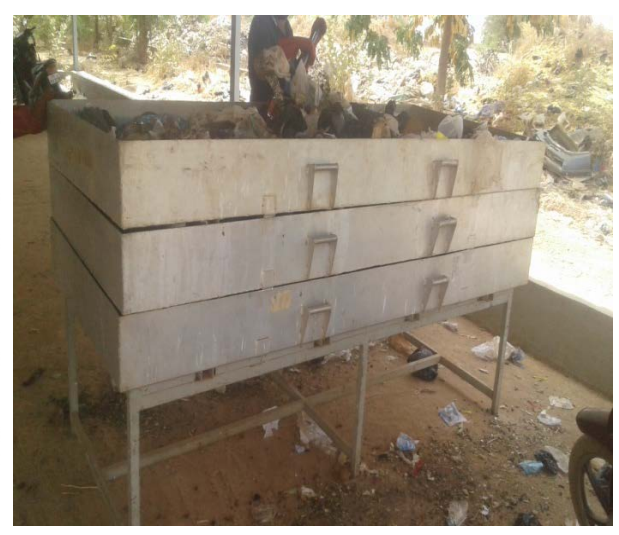

(b)

Figure 4. Sorting table: (a) illustration mesh; (b) sorting operation by size.

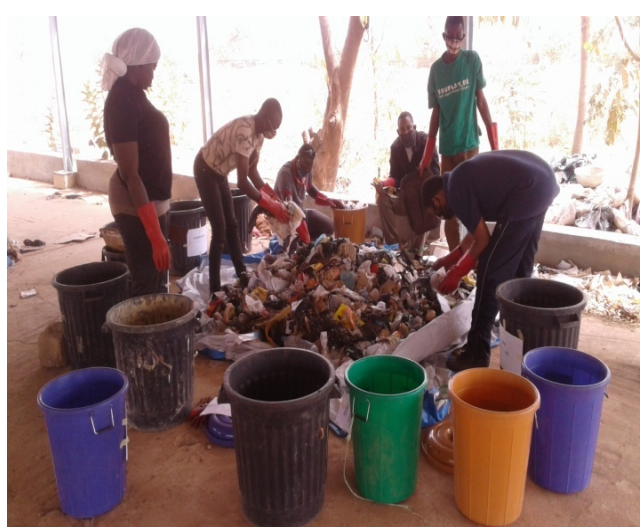

Figure 5. Sorting operation by category. 
waste was constant (Figure 6).

The moisture content was calculated as follow. For given waste category $i$, this percentage of moisture $\left(H u_{i}\right)$ was calculated by the formula in Equation (3).

$$
H u_{i}=\frac{M_{\text {initial }}-M_{\text {dried }}}{M_{\text {initial }}} \times 100
$$

where $M_{\text {initial }}$ is the mass in grams of the heavy waste and $M_{\text {dried }}$, the mass in grams of the heavy waste after drying.

For mixed waste, the total percentage of humidity $\left(H u_{t}\right)$ was calculated by the formula in Equation (4).

$$
H u_{t}=100 \times \sum_{i} H u_{i} \times X_{i}
$$

where $H u_{i}$ is the percentage of humidity of waste category $i$ and $X_{i}$, the percentage of waste category $i$ fraction.

4) Composition by potential of waste recovery

The potential of recovery is any operation aiming the waste recovery mainly matter recovery, and organic recovery. Matter recovery is any operation (recycling, reuse and re-use) aimed at giving a new use to the matter or to the object that makes up the waste or to a raw material. Organic recovery is any operation aiming at composting or mechanization.

The percentage composition of each of the components of these modes (percentage composition of recovery) was calculated by the formula in Equation (5).

Percentage composition of recovery $=\sum$ (percentage composition by category $)$

where $i$ refers to concerned waste fraction. The percentage composition of waste

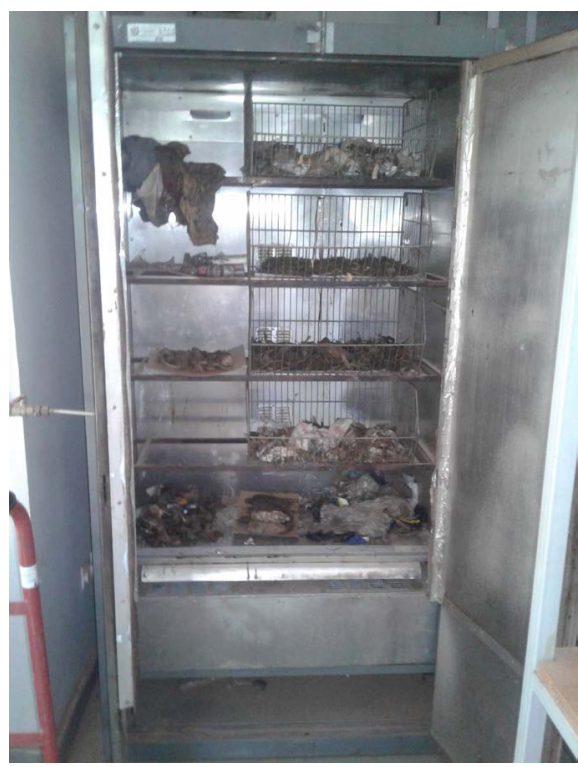

(a)

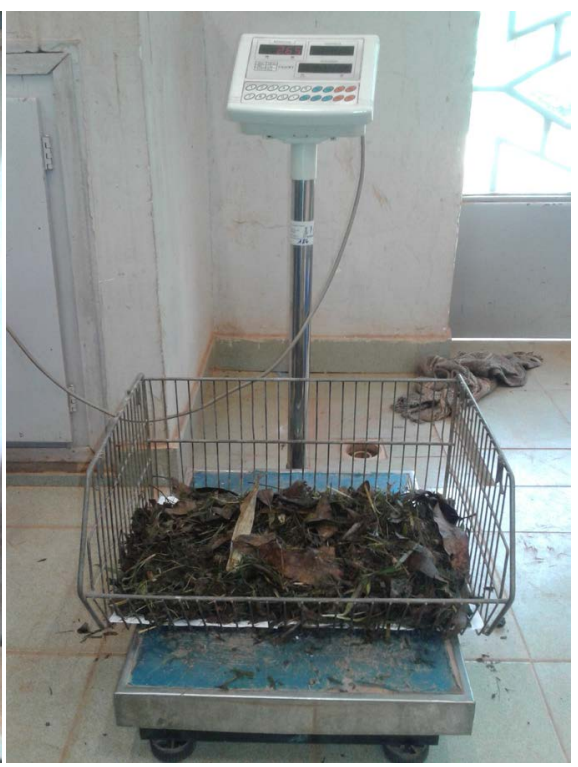

(b)

Figure 6. Determination of moisture content of waste: (a) waste drying in an oven; (b) Dried waste weighing. 
fraction is given by Equation (2).

The repartition of concerned waste fraction for each of the modes of waste recovery is given as:

- Matter recovery: papers, cardboards, textiles, plastics, glasses and metals.

- Organic recovery: fermentable waste, papers, cardboards and sanitary textiles.

5) Energy content

Numerous works are shown that the energy content of the waste is a function of physical composition of the waste, moisture content and ash content [22] [23] [24] [25]. According to the literature on the subject, there is an inconsistency in the term used to report the energy content. It is described as higher heating/heat value (HHV), lower heating/heat value (LHV), lower calorific value (LCV), net heating/heat or gross heating/heat value [22]. A discussion on these descriptions can be found in [22] [25].

Several empirical models have been developed to describe and predict the energy content of HSW [22] [23] [24] [25]. For the present work, HHV (respectively LHV) in $\mathrm{KJ} / \mathrm{kg}$ was calculated by the formula in Equation (6) (respectively in Equation (7)) [25].

$$
\begin{gathered}
\mathrm{HHV}=112.815 \times \mathrm{Or}+184.366 \times \mathrm{Pa}+298.343 \times \mathrm{Pl}-1.92 \times \mathrm{Hu}+5130.38 \\
\mathrm{LHV}=\mathrm{HHV} \times(1-\mathrm{Hu})-2.443 \times \mathrm{Hu}
\end{gathered}
$$

where $\mathrm{Or}$ is the percentage of organic fraction (fermentable waste and sanitary textiles), $\mathrm{Pa}$ the percentage of paper fraction (papers, cardboards and non-classified combustibles), $\mathrm{Pl}$ the percentage of plastics, and, $\mathrm{Hu}$, the percentage of moisture.

\section{Results and Discussion}

\subsection{Composition by Size}

Table 1 and Figure 7 present the results of the composition by size. In the rainy season, the fraction of the fines is approximately $38 \%$, the means $29 \%$ and the big $33 \%$. In the dry season, they are respectively $38 \%, 20 \%$ and $42 \%$. The dominant fraction is fines in the rainy season whereas it is the big in the dry season. The discrepancy between these seasons is approximately $0 \%,+9 \%$ and $-9 \%$ respectively for the fines, the means and the big. The sign plus refers to higher percentage composition of fraction in rainy season. These observations can be related to rains that decompose the big (cardboard/paper) into means.

As Compared to results of Tezanou et al. [3] of 2003 year, we notice an important decrease of the fines fraction in favor of big fraction in each season. This is mainly due to the increase of asphalt roads, to the activities of sand recovery through the daily sweeping of the roads.

\subsection{Composition by Category of Waste}

Figure 8 shows the results of the composition by category of waste with respect to the three zones (low standing, middle standing and high standing). Table 2 
Table 1. Composition by size. The data in parentheses correspond to results published by Tezanou et al. [3].

\begin{tabular}{ccc}
\hline \multirow{2}{*}{ Particle size $(d)$} & \multicolumn{2}{c}{ Percentage composition of size fraction } \\
\cline { 2 - 3 } & Rainy season & Dry season \\
\hline Fines $(d<20 \mathrm{~mm})$ & $38.27(71)$ & $38.08(74)$ \\
Means $(20 \mathrm{~mm} \leq d<100 \mathrm{~mm})$ & $28.70(14)$ & $19.96(17)$ \\
$\operatorname{Big}(d \geq 100 \mathrm{~mm})$ & $33.03(15)$ & $41.95(9)$ \\
\hline
\end{tabular}

Table 2. Composition by category of waste. Results given by Tezanou et al. [3] are presented for comparison.

\begin{tabular}{|c|c|c|c|c|c|c|}
\hline \multirow[b]{3}{*}{ Category of waste } & \multicolumn{6}{|c|}{ Percentage composition of waste fraction } \\
\hline & \multicolumn{3}{|c|}{ Rainy season } & \multicolumn{3}{|c|}{ Dry season } \\
\hline & $\begin{array}{l}\text { Present } \\
\text { work } \\
\text { (with } \\
\text { fines) }\end{array}$ & $\begin{array}{l}\text { Present work } \\
\text { (without } \\
\text { fines) }\end{array}$ & $\begin{array}{c}\text { Tezanou } \\
\text { et al. } \\
\text { (without } \\
\text { fines) }\end{array}$ & $\begin{array}{l}\text { Present } \\
\text { work } \\
\text { (with } \\
\text { fines) }\end{array}$ & $\begin{array}{c}\text { Present } \\
\text { work } \\
\text { (without } \\
\text { fines) }\end{array}$ & $\begin{array}{l}\text { Tezanou et } \\
\text { al. (without } \\
\text { fines) }\end{array}$ \\
\hline Fermentable waste & 23.86 & 38.66 & 43 & 19.94 & 32.2 & 39 \\
\hline Paper & 1.65 & 2.67 & 2 & 2.37 & 3.83 & 5 \\
\hline Cardboard & 4.49 & 7.27 & 9 & 5.19 & 8.39 & 4 \\
\hline Composites & 1.53 & 2.48 & 2 & 2.28 & 3.68 & 4 \\
\hline Textiles & 5.41 & 8.76 & 9 & 4.32 & 6.97 & 5 \\
\hline Sanitary textiles & 1.69 & 2.74 & 0 & 1.94 & 3.13 & 2 \\
\hline Plastics & 11.13 & 18.02 & 12 & 12.1 & 19.54 & 10 \\
\hline NCC & 3.46 & 5.61 & 3 & 2.81 & 4.54 & 5 \\
\hline Glass & 1.14 & 1.84 & 1 & 3 & 4.85 & 3 \\
\hline Metals & 2.89 & 4.67 & 5 & 1.71 & 2.77 & 4 \\
\hline $\mathrm{NCI}$ & 4.27 & 6.92 & 14 & 5.12 & 8.27 & 17 \\
\hline Special wastes & 0.22 & 0.35 & 0 & 1.14 & 1.84 & 2 \\
\hline Fine materials & 38.27 & - & & 38.08 & - & \\
\hline Total & 100 & 100 & 100 & 100 & 100 & 100 \\
\hline
\end{tabular}

shows the results of the composition by category of waste for the study area. It appears that regardless the season, HSW fractions were dominated by fine materials followed fermentable waste and plastics. The percentage of fine materials is relatively lower for the HSW of high standing. HSW fractions were dominated by fine materials followed fermentable waste and plastics. It should be noted that the lower values in percentage composition of metals and glasses fractions is due to the development of recycling and reusing practices during the last decade. The no sensitive evolution of waste paper, cardboard or plastic fraction with respect to season is due to the source of these materials which is particularly connected to the industrial, commercial or administrative activity.

Comparing to the results previously published by Tezanou et al. [3], the percentage of non-classified incombustibles (NCI) is approximately devised by two. This is due to the source of these materials which is particularly connected to the construction activity with an increase in wastes recycling or reusing as scrap, broken tiles, etc. 


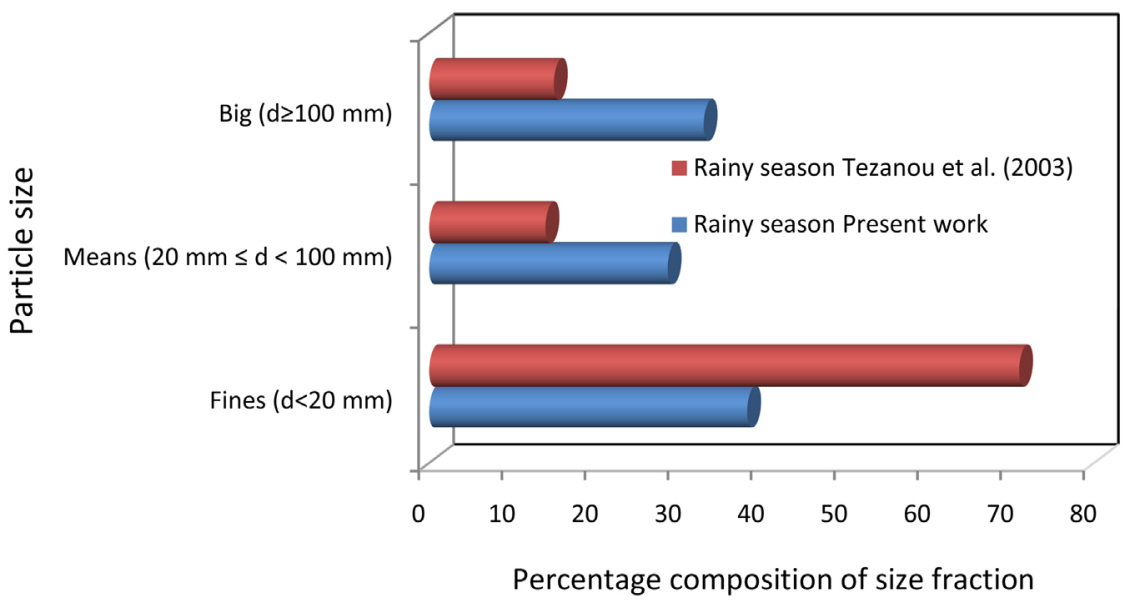

(a)

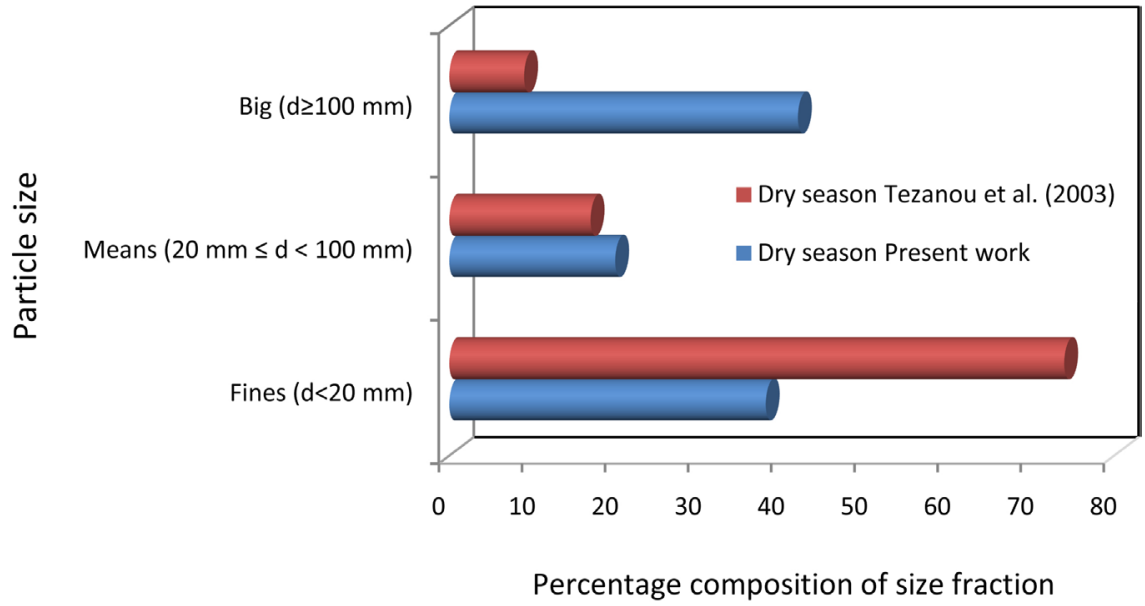

(b)

Figure 7. Distribution of composition by size of waste: (a) rainy season; (b) dry season.

\subsection{Moisture Content}

The Table 3 presents the results of the moisture content of HSW in the city of Ouagadougou during the year 2017. As a result, the value of $56.69 \%$ and $37.69 \%$ is obtained respectively in rainy season and dry season. It clearly appears that the moisture content is sensitive to season.

With respect to the results of Tezanou et al. [3] for the year 2003, the obtained values are 1.64 times higher in the rainy season and 2.4 times in the dry season. This is due to the characteristics of the fines materials which are mainly sand in opposite to the present work where they are organic.

Our results are within the scope of the results showed by numerous previous works dedicated to main cities of sub-Saharan Africa countries.

\subsection{Estimated Energy Content}

Table 4 presents the results of the estimated content energy of HSW of Ouagadougou city for year 2017 given by Equations (6) and (7). In the rainy season, the value of $17.94 \mathrm{MJ} / \mathrm{kg}$ is obtained for the HHV and $6.38 \mathrm{MJ} / \mathrm{kg}$ for the LHV. 


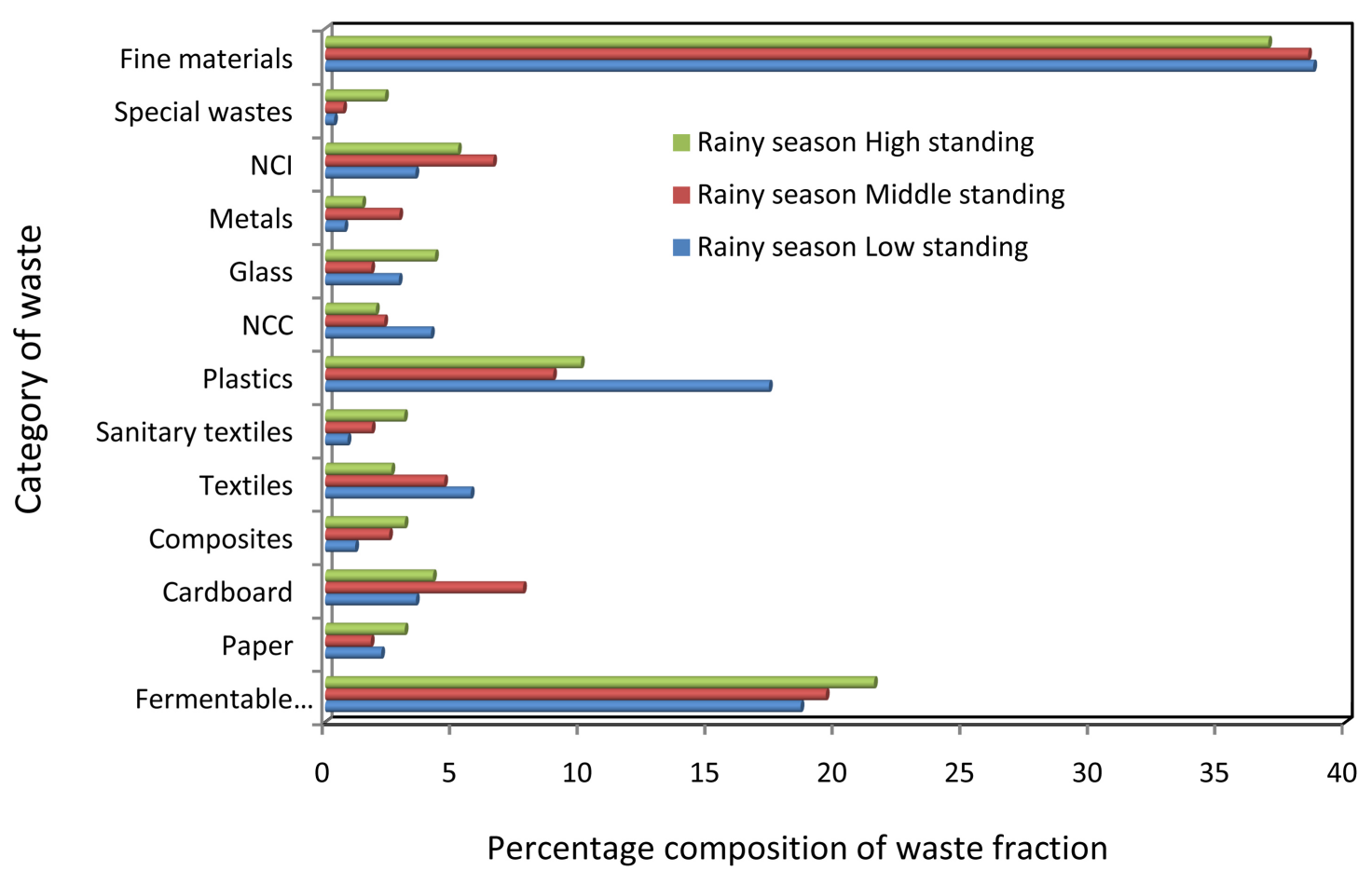

(a)

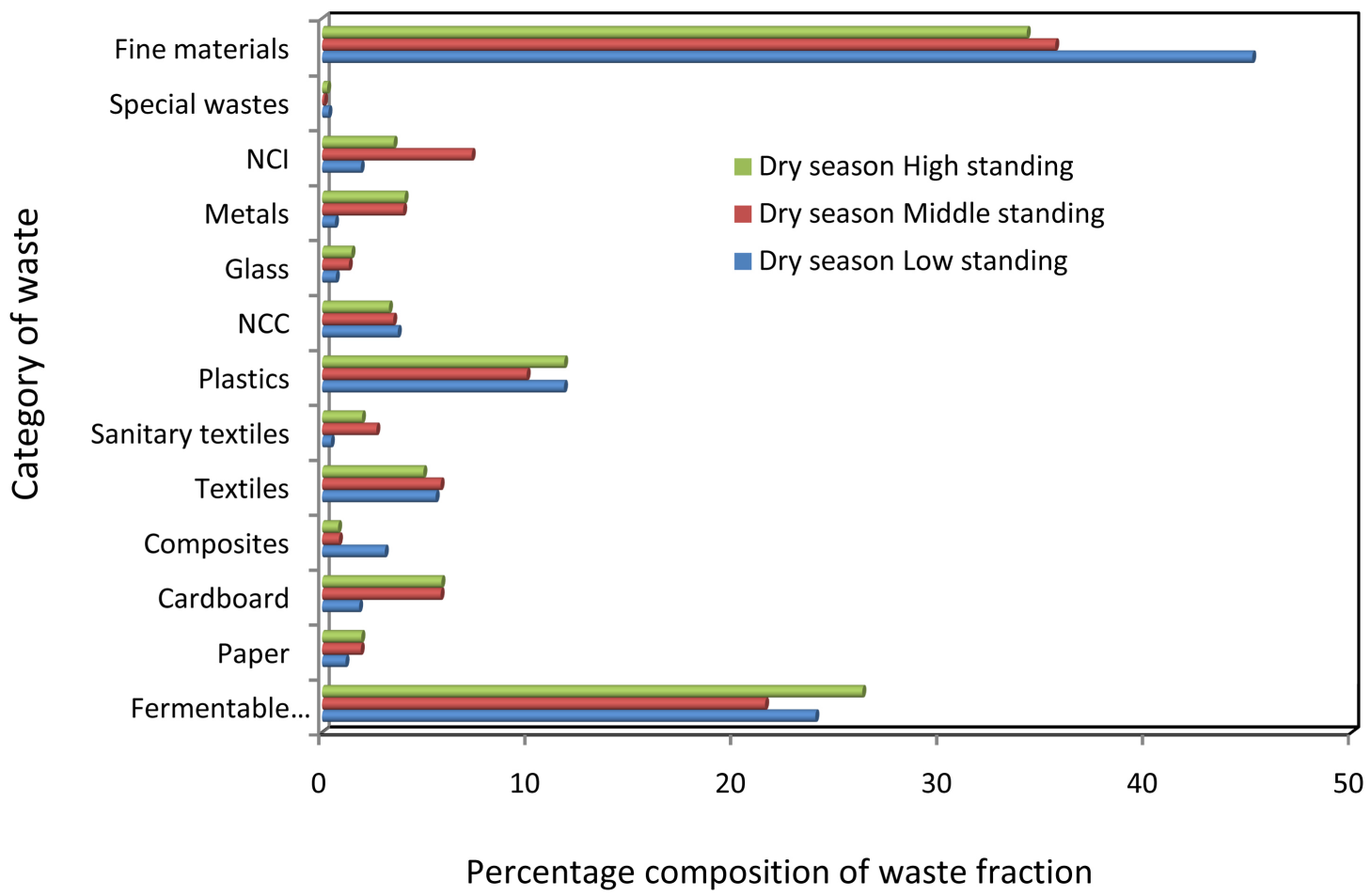

(b)

Figure 8. Distribution of composition by category of waste with respect to the three zones. (a) rainy season; (b) dry season.

In the dry season, they are $17.96 \mathrm{MJ} / \mathrm{kg}$ and $10.27 \mathrm{MJ} / \mathrm{kg}$ respectively for HHV and LHW. These values are in agreement with previous calculations of Seeling 
Table 3. Moisture content by season.

\begin{tabular}{|c|c|c|c|}
\hline \multirow{2}{*}{ Season } & \multicolumn{3}{|c|}{ Moisture content (\%) } \\
\hline & Present work & Tezanou et al. [3] & Other previous works \\
\hline Rainy season & 56.69 & 34 & $21.66^{(\mathrm{a})}, 58^{(\mathrm{b})}, 40-60^{(\mathrm{c})}, 50^{(\mathrm{d})}, 55-57^{(\mathrm{e})}$ \\
\hline Dry season & 37.69 & 15.7 & $16.13^{(\mathrm{a})}, 36^{(\mathrm{b})}, 40-60^{(\mathrm{c})}, 50^{(\mathrm{d})}, 56-70^{(\mathrm{e})}$ \\
\hline
\end{tabular}

Table 4. Estimated energy content.

\begin{tabular}{ccccc}
\hline \multirow{2}{*}{ Season } & \multicolumn{4}{c}{ Energy content $(\mathrm{MJ} / \mathrm{kg})$} \\
\cline { 2 - 5 } & \multicolumn{3}{c}{ Present work } & Tezanou et al. [3] \\
\cline { 2 - 5 } & HHV & LHV & HHV & LHV \\
\hline Rainy season & 17.94 & 6.38 & 16.08 & 9.78 \\
Dry season & 17.96 & 10.27 & 15.29 & 12.51 \\
\hline
\end{tabular}

and Schneider [25] using the same equations for Porto Alegre's HSW. These results show that the estimated HHV does not present seasonal variations in opposite to the LHV.

In fact, according to Equation (6), the constant related to the plastics fraction is 2.64 times the constant related to the organic fraction and 1.62 times the constant related to the papers fraction. When subtracting the percentage composition of waste fraction in rainy season to this in dry season (Table 2), the discrepancy is $+6.07 \%,-1.21 \%$ and $-1.51 \%$ respectively between the organic fraction, the paper fraction and the plastics fraction. This gives rise to compensation in the HHV calculation in rainy and dry seasons

$\left(\frac{+6.07 \%}{2.64}+\frac{-1.21 \%}{1.62}+\frac{-1.51 \%}{1}=0.03 \%\right)$.

Also, according to Equation (7), the LHV is not favored by a high percentage of moisture. In the present case, the percentage of moisture in rainy season is 1.5 times the percentage of moisture in dry season. This gives rise to a low value of LHV in rainy season in comparison to this value in dry season.

The comparison of the present results and those of Tezanou et al. [3] shows that the values of HHV are similar whereas the values of LHV are lower for the present work. The high values of moisture given by the present work (Table 3) explain the low value of LHV for the present work as mentioned above.

According to the literature [25] [29], waste cannot be incinerated without external energy supply if the average LHV is less than $6 \mathrm{MJ} / \mathrm{kg}$ throughout all seasons and the annual average LHV less than $7 \mathrm{MJ} / \mathrm{kg}$. Given the obtained values, incineration is not economically an appropriate option.

\subsection{Composition by Potential of Waste Recovery}

Table 5 presents the obtained results of composition by potential of waste recovery. Regardless the season, fraction of recovery modes was dominated by the 
Table 5. Composition by potential of waste recovery. Values in parentheses are previous results of Tezanou et al. [3].

\begin{tabular}{ccc}
\hline \multirow{2}{*}{ Recovery mode } & \multicolumn{2}{c}{ Percentage composition of recovery fraction } \\
\cline { 2 - 3 } & Rainy season & Dry season \\
\hline Matter recovery & $43.23(38)$ & $46.35(31)$ \\
Organic recovery & $60.10(63)$ & $54.52(55)$ \\
\hline
\end{tabular}

organic recovery ( $60 \%$ in the rainy season and $55 \%$ in the dry season) followed by the matter recovery ( $43 \%$ in the rainy season and $46 \%$ in the dry season). It should be noticed that values of this mode of recovery must be higher because of the development of recycling and used practices to the source by chests of drawers.

Globally, there is no sensitive evolution of percentage composition of recovery fraction with respect to reason. These results highlight the opportunities for organic recovery of HSW in the city of Ouagadougou.

When comparing the present to those of Tezanou et al. [3], we notice that only the percentage of composition of matter recovery exhibits a sensitive evolution. This is due to the development of recycling and used practices as previously mentioned.

\section{Summary and Conclusions}

The physical and the physicochemical characteristics of the household solid waste (HSW) in the city of Ouagadougou have been studied by means of MODECOM method. We obtained that in terms of waste repartition by size, the fraction of the fines is approximately $38 \%$, the means $29 \%$ and the big $33 \%$ in the rainy season. In the dry season, they are respectively $38 \%, 20 \%$ and $42 \%$. In terms of waste reparation by category, regardless the seasons, fractions of HSW were dominated by fermentable waste (39\% in the rainy season and $20 \%$ at dry season) and plastics ( $18 \%$ in the rainy season and $20 \%$ in the dry season). The measured value of moisture content is $56.69 \%$ and $37.69 \%$ respectively for the rainy and dry seasons.

Estimates of the content energy show that the values of $17.94 \mathrm{MJ} / \mathrm{kg}$ are obtained for the HHV and y $6.38 \mathrm{MJ} / \mathrm{k}$ ) for the LHV in the rainy season. In the dry season, they are $17.96 \mathrm{MJ} / \mathrm{kg}$ for the HHV) and $10.27 \mathrm{MJ} / \mathrm{kg}$ for the LHW. These results suggest that incineration is not economically an appropriate option.

The results of the potential of waste recovery show that regardless the season, the potential of recovery was dominated by the organic recovery $(60 \%$ in the rainy season and $55 \%$ in the dry season) followed by the matter recovery ( $43 \%$ in the rainy season and $46 \%$ in the dry season). These results highlight the need for organic recovery and matter recovery of HSW in the city of Ouagadougou. With respect to the results of waste characterization for the year 2003, the present results for the year 2017 show a sensitive evolution of the waste characteristics. The percentage of the fines fraction has decreased in favor of big fraction. This is 
mainly due to the activities of sand recovery through the daily sweeping of the roads. The percentage of non-classified incombustibles (NCI) is approximately devised by two with respect to increase in wastes recycling or reusing as scrap, broken tiles, etc. The percentage of plastics that are mainly bags used commercial activities has increased. The percentages of moisture are 1.64 times higher in the rainy season and 2.4 times in the dry season.

\section{References}

[1] Beede, D.N. and Bloom, D.E. (2010) The Economics of Municipal Solid Waste. World Bank Researh Observer, 10, 113-150. https://doi.org/10.1093/wbro/10.2.113

[2] The World Bank (2000) Municipal Solid Waste Incineration: Requirements for a Successful Project. Technical Guidance Report, Washington DC.

[3] Tezanou, J., Koulidiati, J., Rogaume, T., Jabouille, F., Andzi Barhe, F.T., Sougoti, M., Kafando, P., Segda, B.G., Goudeau, J.C. and Joulan, P. (2003) Experimental Characterization of Household Waste in Developing Countries: Case of the City of Ouagadougou (Burkina Faso). Annales de l'Université de Ouagadougou Série C: Sciences de la Vie et de la Matière, 1, 54-83.

[4] Ukondaleba, L.M., Lina Aleke, A., Ngahane, E.L., Musibono Eyul'Anki, D. and Vasel, J.L., (2016) Valorization of Organic Houshold Waste and Septic Tank Sludge by Anerobic Digestion. International Journal of Innovation and Scientific Research, 20, 272-281.

[5] Yemadje Alda, A.S., Edorh Patrick, A., Aina Martin, P., Kissao, G., Houssou S.C., Boko, M. and Tougan U.P. (2013) Characterization of the Household Solid Waste of the Municipality of Abomey-Calavi in Benin. Journal of Environmental Research and Management, 4, 368-378.

[6] Topanou, N., Domeizel, M., Fatombi, J., Josse, R.G. and Aminou, T. (2011) Characterization of Household Solid Waste in the town of Abomey-Calavi in Benin. Journal of Environmental Protection, 2, 692-699.

https://doi.org/10.4236/jep.2011.26080

[7] Miezah, K., Obiri-Danso, K., Kádár, Z., Fei-Baffoe, B. and Mensah, M.Y. (2015) Municipal Solid Waste Characterization and Quantification as a Measure towards Effective Waste Management. Ghana Waste Managemen, 46, 15-27. https://doi.org/10.1016/j.wasman.2015.09.009

[8] Oteng-Ababio, M., Arguello, J.E.M. and Gabbay, O. (2013) Solid Waste Management in African Cities: Sorting the Facts from the Fads in Accra, Ghana. Habitat International, 39, 96-104. https://doi.org/10.1016/j.habitatint.2012.10.010

[9] Kuleape, R., Cobbinah, S.J., Dampare, S.B., Duwiejuah, A.B., Amoako, E.E. and Asare, W. (2014) Assessment of Energy Recovery Potential of Solid Waste Generated in Akosombo Ghana. African Journal of Environnmental Science and Technology, 8, 297-308. https://doi.org/10.5897/AJEST2014.1663

[10] Edem, K., Kwamivi, S., Tcha-Thom, M., Baba, G., Mateka, G. and Tchangbedj, G. (2016) Impact of Togo's Urbans Solids Wastes Sorting and Composting on the Total Content of Hevay Metals. Asian Journal of Applied Sciences, 9, 113-119. https://doi.org/10.3923/ajaps.2016.113.119

[11] Ndongo, B., Fonteh, M.F., Jiofack, L.N. and Mbouendeu, S.L. (2016) Residential Solid Waste Management in Cities with Developing Economics: Case Study of Yaoundé, Cameroon. IOSR Journal of Environnmental Science, Toxicology and Food Technology, 10, 34-43. 
[12] Ngnikam, Wethe, E., J., Tanawa, E., and Riedacker, A. (1998) Composting of Household Waste to Clean Streets and Increase Crop Yields in Yaounde: A Solution for Poor African Cities. In: El Bassam, N., Behl, R.K. and Prochnow, B., Eds., Sustainable Agriculture for Food, Energy and Industry. Vol 2: Strategies towards Achievement. James \&James (Science Publishers) Ltd, London, 1286-1291.

[13] Nabegu, A.B. (2010) An Analysis of Municipal Solid Waste in Kano Metropolis. Nigeria Journal of Human Ecology, 31, 111-119. https://doi.org/10.1080/09709274.2010.11906301

[14] Abur, B.T., Oguche, E.E. and Duvuna, D.A. (2014) Characterization of Municipal Solid Waste in the Federal Capital, Abuja, Nigeria. Global Journal of Science Frontier Research: H. Environnment \& Earth Science, 14, No. 2.

[15] Oluwafemi, O. and Bowen, D.M. (2014) Environmental and Economic Analysis of Solid Waste Management Alternatives for Lagos Municipalities, Nigeria. Journal Sustainable Development in Africa, 16, 1520-1526.

[16] Sankoh, F.P., Yan, X. and Conteh, M.H. (2012) A Situation Assessment of Socioeconomic Factors Affecting Solid Waste Generation and Composition in Freetown, Sierra Leone. Journal of Environmental Protection, 3, 562-568.

[17] Saidou, H. and Aminou, S.(2015) Solid Waste Management in the Town of Maradi in Niger Republic. Journal of Environnmental Protection, 6, 359-376.

[18] The Nationsl Institute of Statistics and Demography (2015) Statistical Yearbook. http://www.insd.bf/n/contenu/pub_periodiques/annuaires_stat/Annuaires_stat_nati onaux_BF/Annuaire_stat_2015.pdf

[19] ADEME (MODECOM, 1993) (1993) Method of Characterization of Household Waste. ADEME Editions.

[20] Sory, I. and Abdramane, S. (2015) L'ingénierie spatiale à l'épreuve des jeux d'acteurs: dynamiques des territoires de pré-collecte des déchets à Ouagadougou (Burkina Faso). Territoire en mouvement-Revue de géographie et aménagement, 27-28.

[21] Direction of Studies and Planning-Ouagadougou Municpality-Burkina Faso (2011) Statistical Yearbook 2010.

[22] Kathiravale, S., Yunus, M., Sopian, K., Samsuddin, A. and Rahman, R. (2003) Modeling the Heating Value of Municipal Solid Waste. Fuel, 82, 1119-1125.

[23] Abu-qudais, M. and Abu-qdais, H.A. (2000) Energy Content of Municipal Solid Waste in Jordan and Its Potential Utilization. Energy Conversion and Management, 41, 983-991. https://doi.org/10.1016/S0196-8904(99)00155-7

[24] Usón, A., Ferreira, G., Vásquez, D., Bribián, I. and Sastresa, E. (2012) Estimation of the Energy Content of the Residual Fraction Refused by MBT Plants: A Case Study in Zaragoza's MBT Plant. Journal of Cleaner Production, 20, 38-46. https://doi.org/10.1016/j.jclepro.2011.07.024

[25] Seelig, M.F. and Schneider, P.S. (2012) Estimating the Energy Content of Municipal Solid Waste from Its Physical Composition: The Heat of Combustion of Porto Alegre's Household Solid Waste. Brazilian Congress of Thermal Sciences and Engineering, 14, 14-18.

[26] Fobil, J.N., Carboo, D. and Armah, N.A. (2005) Evaluation of Municipal Solid Wastes (MSW) for Utilisation in Energy Production in Developing Countries. International Journal Environmental Technology and Management, 5, 76-86. https://doi.org/10.1504/IJETM.2005.006508

[27] Adu, R.O. and Lohmueller, R. (2012) The Use of Organic Waste as an Eco-Efficient 
Energy Source in Ghana. Journal of Environmental Protection, 3, 553-562.

[28] Tahraoui, D.N., Matejka, G., Chambon, S. and Touil, D. (2016) Composition for Municipal Solid Waste Generated by the City of Chelf (Algeria). Energy Procedia, 18, 762-771.

[29] The World Bank (1999) Municipal Solid Waste Incineration. Technical Guidance Report. 